\section{International Scientific Journal Theoretical \& Applied Science}

p-ISSN: 2308-4944 (print) $\quad$ e-ISSN: 2409-0085 (online)

Year: 2015 Issue: 04 Volume: 24

Published: $30.04 .2015 \quad \underline{\text { http://T-Science.org }}$

SECTION 4. Computer science, computer engineering and automation.
Manshuk Maksutovna Abdimomynova Candidate of Technical Sciences, Associate professor Taraz State University of M.Kh.Dulati Abdimanshuk@mail.ru

Zhanagul Esenovna Doumcharieva master, senior teacher

Taraz State University of M.Kh.Dulati zhanagu178@mail.ru

Kairanbek Zhandarbekovich Mombayev master, senior teacher

Taraz State University of M.Kh.Dulati kaira_kz@list.ru

\title{
AUTOMATION AND MANAGEMENT OF PROCESS GRAIN DRYING
}

Abstract: Development of computer modeling of process drying of grain and definition of algorithm for automation and management. Ways to improve the process of drying, drying will help to increase the effectiveness of the new structures.

Key words: Automation, controls, algorithm, a computer model, grain drying.

Language: English

Citation: Abdimomynova MM, Doumcharieva ZE, Mombayev KZ (2015) AUTOMATION AND MANAGEMENT OF PROCESS GRAIN DRYING. ISJ Theoretical \& Applied Science 04 (24): 177-184.

Soi: http://s-o-i.org/1.1/TAS*04(24)32 Doi: crossef http://dx.doi.org/10.15863/TAS.2015.04.24.32

\section{UDC 519.685}

In this project, a technological process used creates a computer model of the object-oriented approach. Process control for real-life grain drying drum model is characterized as an object of special programs. Considered real object of the drying process, carried out external relations with the programming. Drying the object can be detected and characterized by its properties:

class Tagregat

\{

private:

float FV_tn; // Speed carrier, m / s

__fastcall TAgregat (void); // Constructor \};

extern TAgregat * Agregat;

Drying the object of the program is defined as a class all of its properties. At the same time, the relationship with the environment is completely determined by properties interface, technological process of drying kinetic equation based on calculation of drying unit's performance. Is determined scientific theoretical research algorithms.

Block diagram the technological drying process computer control system (Fig.1).

Grain drying process is controlled by special defined in the model equations. At the same time, the computer model makes it possible to carry out scientific research. Theoretical and fill in the details with a grain drying process allows to determine the optimal models of operation. Change the actual construction of the grain dryer unit; we can check the operation drying process. Model of the external environment on the basis of the ratio encapsulation mechanism, shall be determined by the properties of the object's interface. The object information from the external environment in the software environment will be pre-screened before, reviewed the terms of the equation that is pre-defined criteria.

Only fully satisfy the conditions of this data are only written inner edge of hidden object. These edges are not visible from the external environment and protected from direct access. This increases the reliability of computer models. As a result of his work in the object model of grain drying use of the following information:

1. The amount of moisture in the first and wheat;

2. The initial and final temperate wheat;

3. The agency used grain drying the first and last temperature and flow rate of total income;

4. Drying drum rotational speed;

5. Drying drum, the angle of inclination of the plains;

6. Wheat seed diameter of the heat;

7. Dryer to dry the product performance;

8. Evaporate moisture on wheat and wheat grain temperature heat capacity;

9. The density of the air used for drying grain, air flow and air kinematical on turnover. 


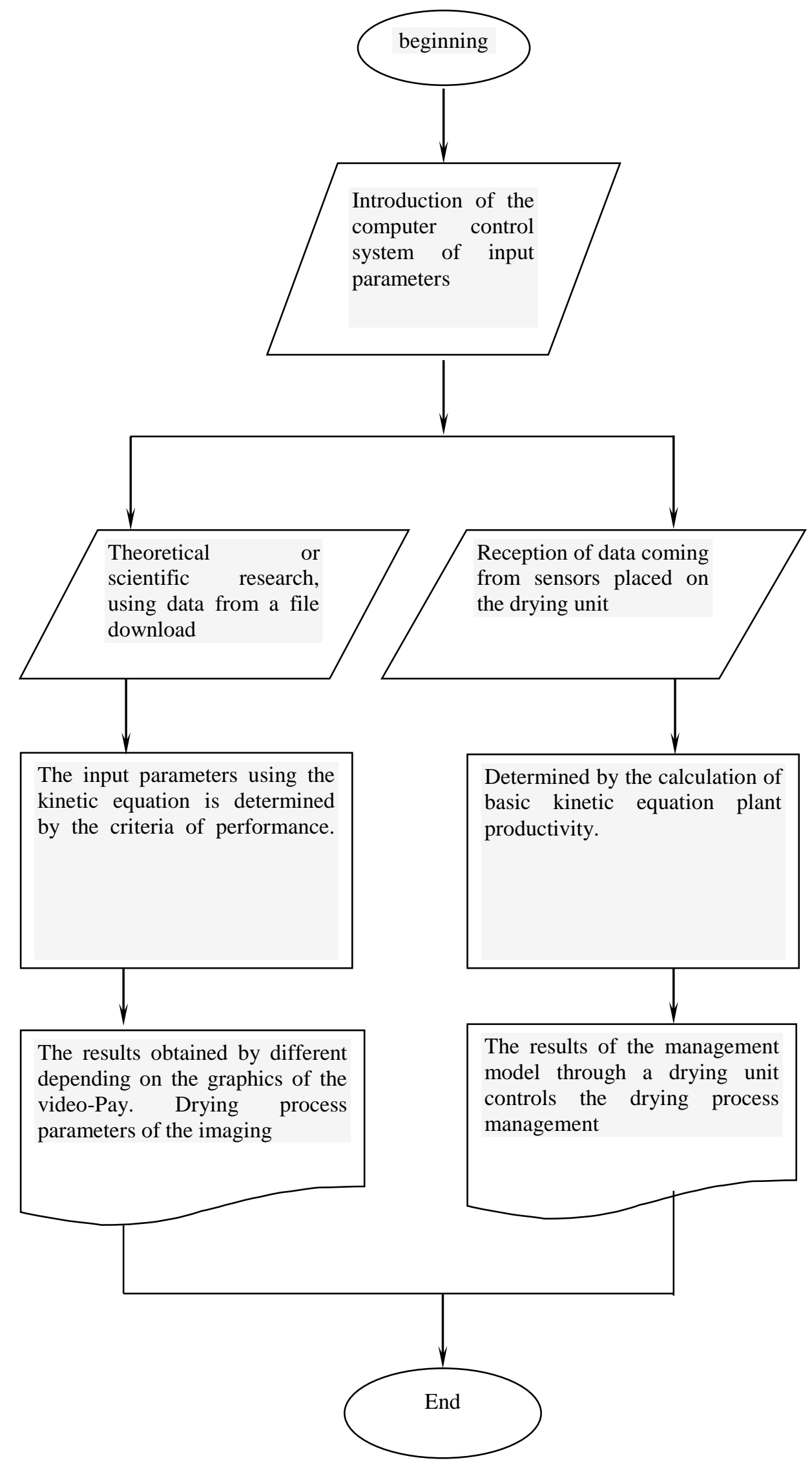

Figure 1 - Block diagram of the technological process of drying. 
$\mathrm{C}++$ input parameters listed above are characterized by the drying properties object in the form of: Mathematical and physical model created in the process of drying, the drying process was the kinetic equation in the form of a set of criteria equations. The management of the technological process of drying of wheat grain products processing plant for the drying drum (1) was chosen as the criteria of the equation.

$$
\text { F (Fo; G / Lm; Ko; E; } \theta ; \text { Re; Fr; } \sin \alpha)=0
$$

Calculating object properties defined criteria:

1. Criteria Reynolds: $2 *$ FV_tn * Fda / FV_kin_v;

2. Humidity simplex: (Fun-FUK) / fun;

3. Fourier criteria: Fa $*$ Ft_sr / pow (t_a, 2);

4. Criteria Froude: $2 *$ pow $(3.14,2) *$ pow $(\mathrm{Fn}, 2) *$ FD_sig / Fg;

5. Criteria crossover: Fr_t $*$ FUn / $(\mathrm{FCm} * \mathrm{FTn})$; 6. The temperature simplex: (FTkm-FTnm) / (FTnFTk);

7. Simplex: FV_tn $* 3.14 *$ pow $($ FD_sig, 2$) *$ FRo_b * (1 psi) / 4;

8. The horizontal angle to the plane of the drum, degrees:

fabs $(\cos ($ DegToRad $(10 *($ Falfa +3$))))$

A study of technological process of drying criteria equations.

$$
\begin{gathered}
\mathrm{E}=\mathrm{A} * \mathrm{Koa} * \mathrm{Fob} *(\mathrm{G} / \mathrm{Lm}) \mathrm{c} * \operatorname{Red} * \theta \mathrm{eFrf} \\
* \operatorname{Cosg} 10(\text { alpha } 3)
\end{gathered}
$$

The analysis of the results experimental work of criteria determined by the value indicators of degree equation and stability, grain drying drum installation process kinetic equations:

E=FK_A*pow(E,FK_a $)^{*}$ pow $\left(R e, F K \_b\right) *$ pow $\left(\left(\mathrm{Fa} /\right.\right.$ pow $\left.\left.\left(\mathrm{t} \_\mathrm{a}, 2\right)\right), \mathrm{FK} \_\mathrm{c}\right) *$ pow(Fr,FK_e $)^{*}$ pow ( L,FK_f)*pow(Teta,FK_g)*pow(Ko,FK_h)* pow(fabs $(\cos (\operatorname{DegToRad}(10 *($ Falfa +3$))))$, FK i)

As a result of the experimental criteria and oversized values varied within the following: $\mathrm{Re}=568,42,1122,63 ; \mathrm{F} 0=38,74,167,24 ; \mathrm{Fr}=$ $0,04,0,23 ;(\mathrm{G} / \mathrm{LM})=0,14,0,85 ; \mathrm{q}=0,22,3,16 ; \mathrm{K} 0$ $=20,67,49,09$

The value of the results of the study found.

Computer model to ensure the proper functioning of the drum drying is necessary to ensure the execution contracts in accordance with the determination properties object. Object drying properties of grain drying process is obtained by carrying out experimental work restrictions. Computer models can be operated in two different data: According to a study of the theoretical and realtime processing of data from the drying unit by calculating the efficiency of the drying unit. External information is drying properties an item of income. Theoretical research data from sensors located on the drying unit or can be downloaded from a file on disk. At the same time, the drying drum in case of a change in the design of the internal kinetic criteria varies in the degree of the equation. In this sense, the computer model is universal. Grain drying process is fully automated.

The optimal technological modes of drying of wheat and practical guidance.

Table 1.

\begin{tabular}{|l|l|l|}
\hline Technological settings work barabannix agregatov & Recommend & Values of units \\
\hline 1. The angle of inclination of the drum & $\mathrm{Grad}$ & $-2,-3$ \\
2. Heat carrier flow rate & $\mathrm{m} / \mathrm{s}$ & $2,9 \div 3,1$ \\
3. The frequency of rotation of the drum & $\mathrm{C} 0$ & $0,2 \div 0,217$ \\
4. The ratio & $\mathrm{C}^{0}$ & $40 \div 42$ \\
5. The temperature of the heat carrier first & & $185 \div 205$ \\
6. The peak temperature of the gases & & $105 \div 110$ \\
\hline
\end{tabular}

Grain drying process automated analysis system, when taking into account the main window (Fig.2): 


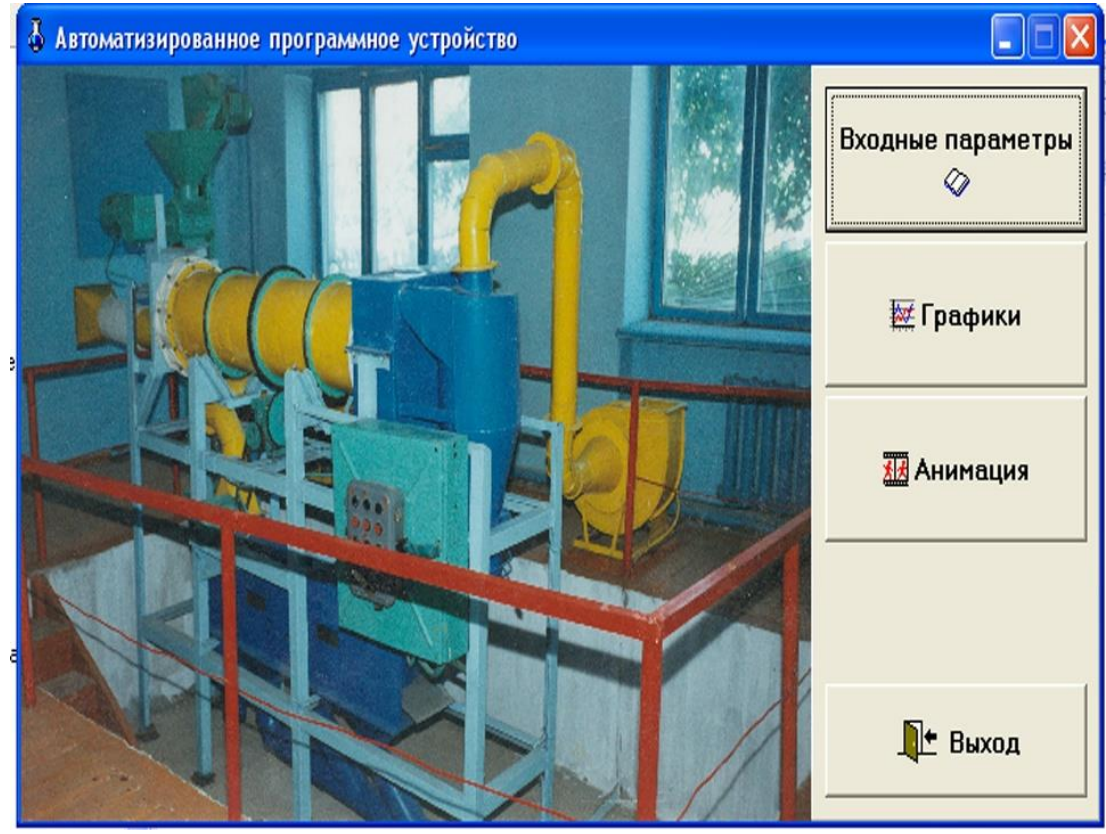

Figure 2 - The main window of the computer program.

The main window of the program consists following menu ways: input, graphics, animation. "Input settings" menu we have ever used a computer model of the entire input parameters program will be included in the box (Fig.3). At the same time, in accordance with the input parameters in this window, drum drying unit performance is clearly related to the location of the plane. "Exit" button to return main window. Theoretically or experimentally obtained values of the input parameters, calculated in a way to fill the schedule, it can be saved to a file. This allows the use of this information in the future other calculations. Input parameter values are indicators of the drying process after a full explanation of criteria. For this purpose, the "Calculate" button must be pressed. During unit design changing mix of wheat, the change the value of the factors in the equation. This is how to improve the process of drying and dry will help to increase the effectiveness of the new structures:

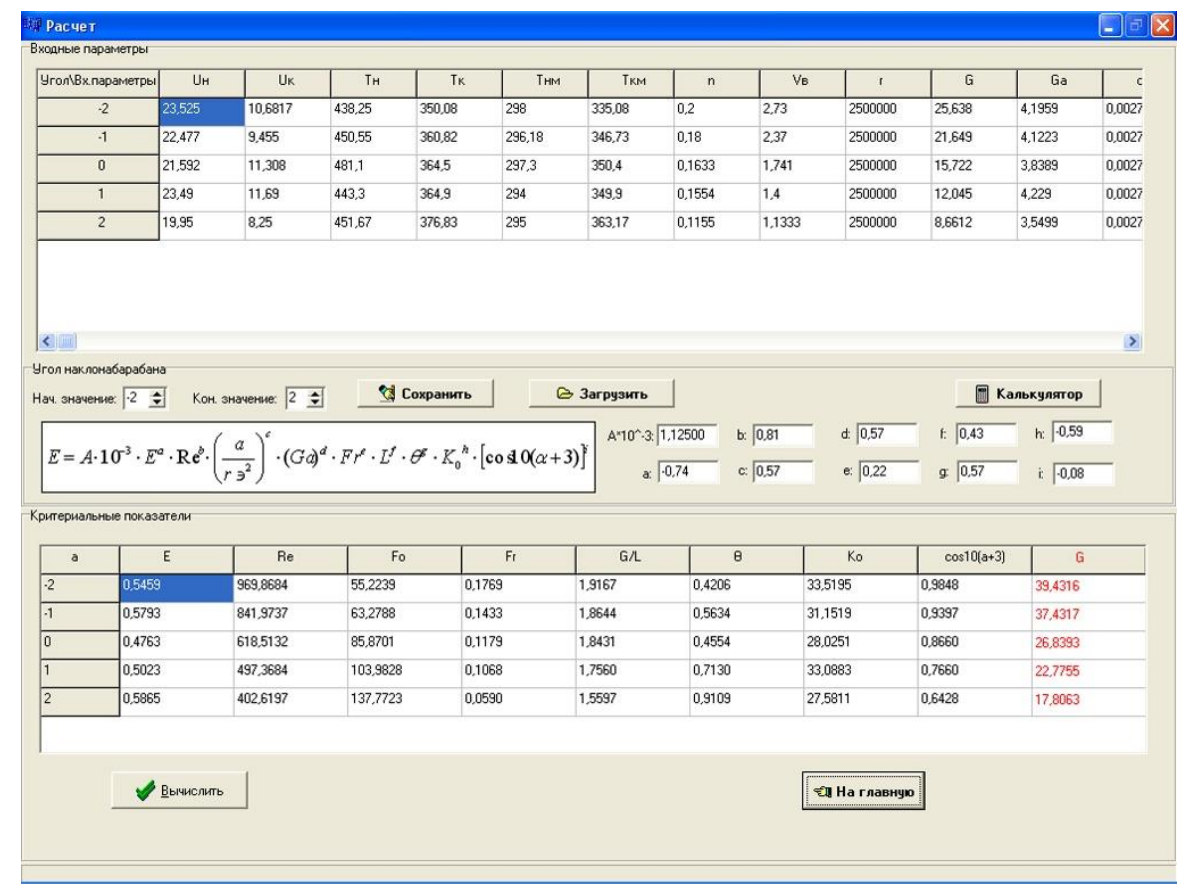

Figure 3 - Computer control system input parameters and criteria for calculating window.

ISPC The Combination of Technology \&

Education, Östersund, Sweden 
Analysis of the results of the calculation is used for a variety of graphs showing the relationship. They open the main window of the program for the "Graphics" menu must be selected. In this window, drum drying unit in the form of the dependence of the different modes graphs. Product dependence of the angle of inclination plane of drum drying (Fig.3).
Drum drying unit shown in the schedule of the temperature dependence of heat carrier. The territory of the transition temperature can be obtained by changing the optimal drying conditions. In accordance with the changes in the program builds a graph (Fig.4).

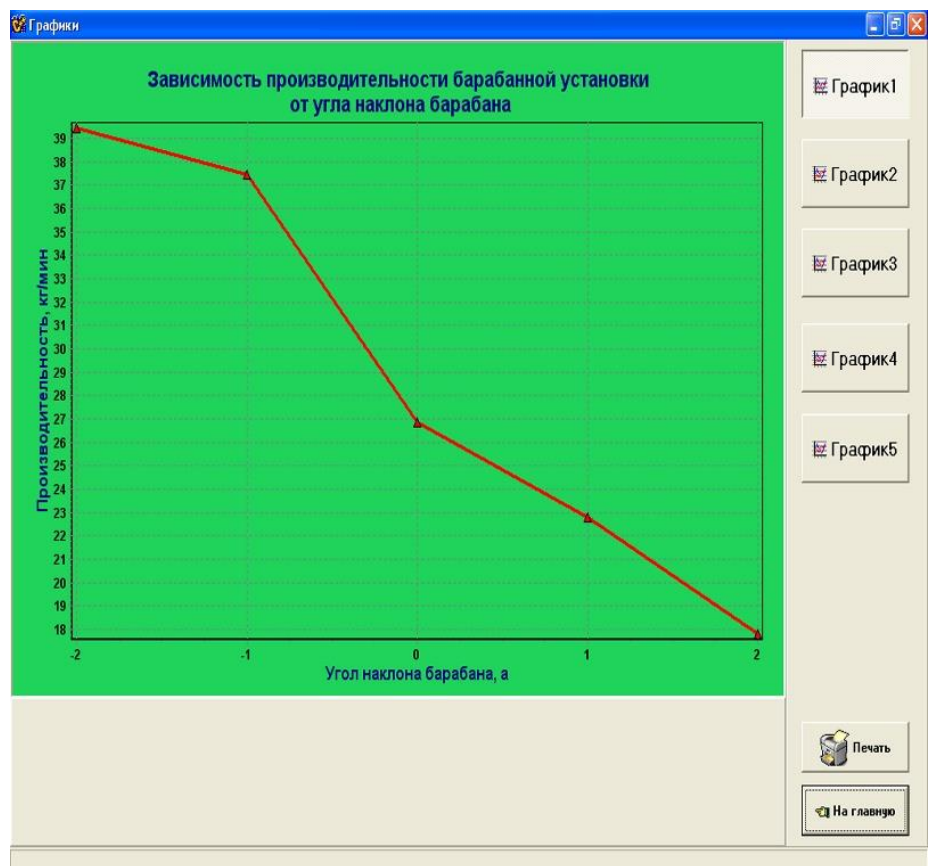

Figure 4 - Drum drying schedule dependence on the angle of inclination of the plane of the drum unit productivity layout.

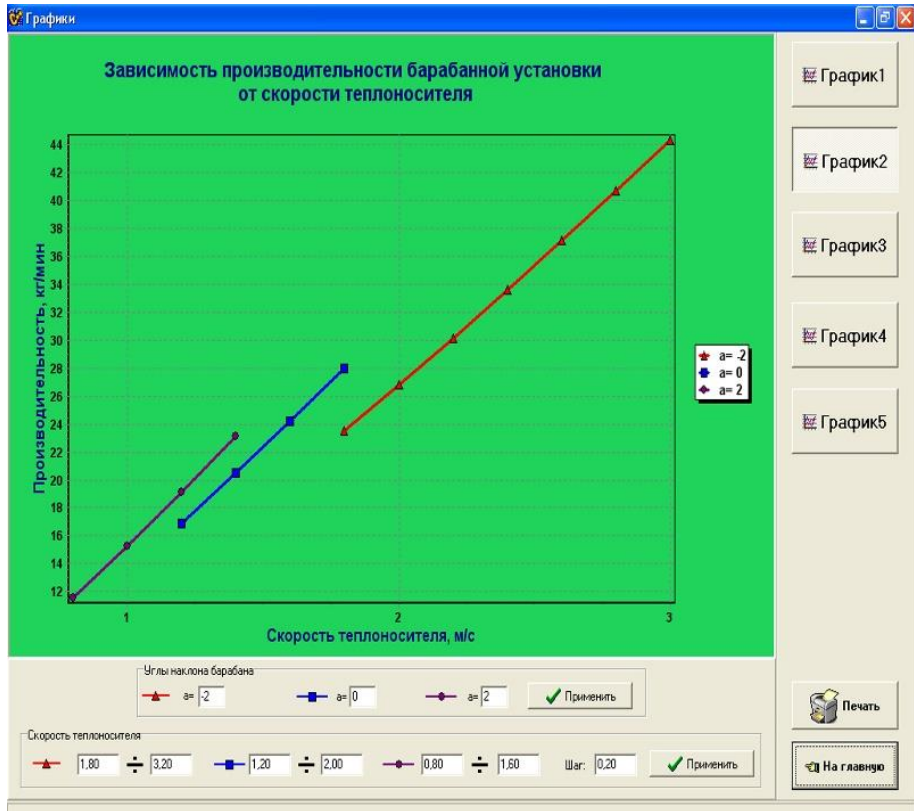

Figure 5 - The drum drying plant productivity and schedule dependent on the speed of the heat carrier.

ISPC The Combination of Technology \& 
Impact Factor ISRA (India) $\quad=\mathbf{1 . 3 4 4}$

Impact Factor ISI (Dubai, UAE) $=\mathbf{0 . 8 2 9}$

based on International Citation Report (ICR)

Impact Factor GIF (Australia) $\quad \mathbf{0} \mathbf{0 . 3 5 6}$
Impact Factor JIF

$=\mathbf{1 . 5 0 0}$

Impact Factor SIS (USA)

$=0.912$

Impact Factor РИНЦ (Russia) $=0.179$

Impact Factor ESJI (KZ) $\quad=\mathbf{1 . 0 4 2}$
Drum drying unit graph shows the frequency of rotation of the drum. The frequency of rotation of the drum, you can change the value of the territory switch. In accordance with the changes in the program builds a graph. Schedule drum drying unit about the temperature dependence of the heat carrier in the bottom of the window. Long temperature can change the value of the territory of the switch. In accordance with the changes in the program builds a graph. Drum drying unit shown in the schedule of wheat seed moisture dependence. Wheat seed humidity can change the value of the territory of the switch. In accordance with the changes in the program builds a graph. All of the above depending on the schedule of the windows can be published.

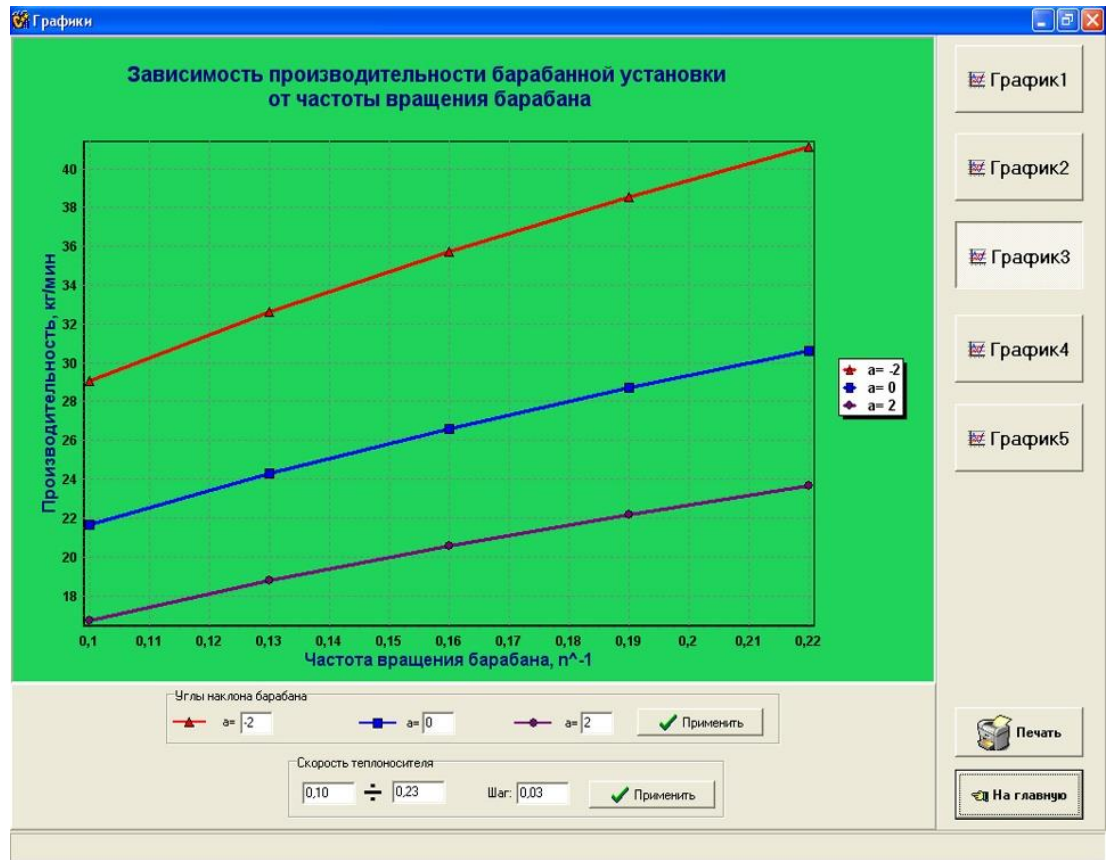

Figure 6 - The drum drying plant productivity graph the frequency of rotation of the drum.

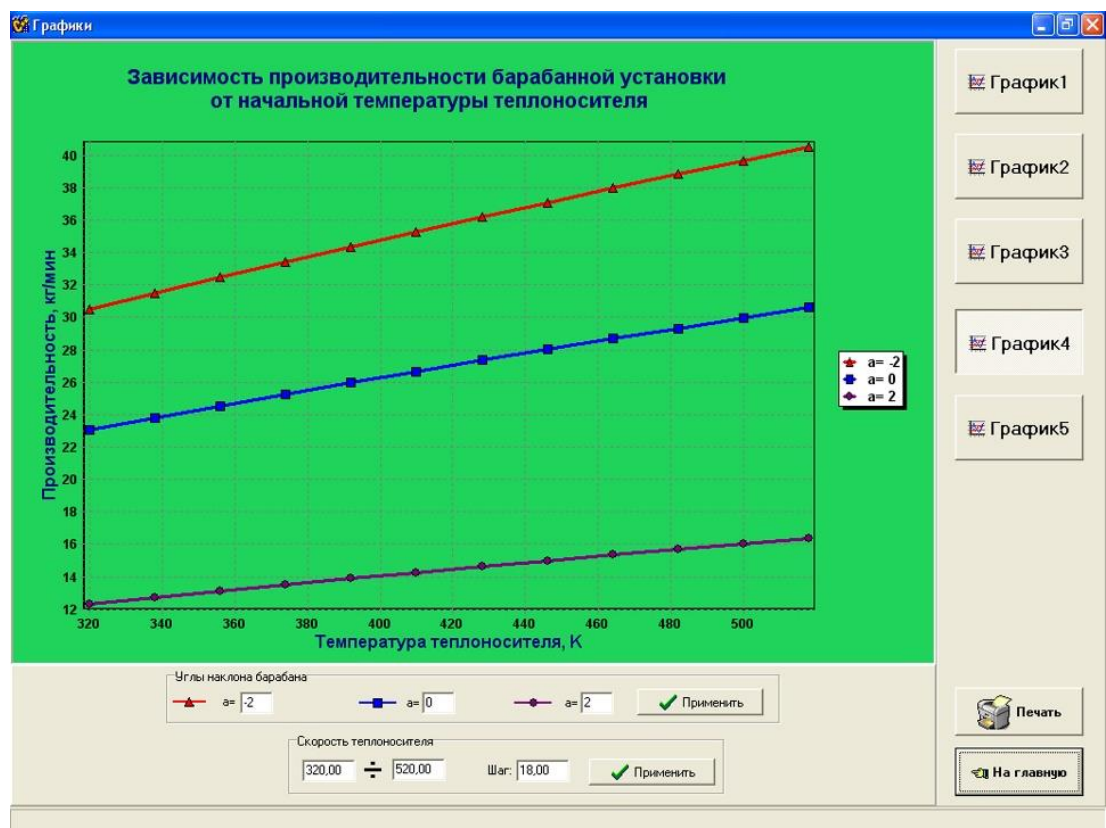

Figure 7 - Drum drying plant productivity in the first schedule of the temperature dependence of the heat carrier. 


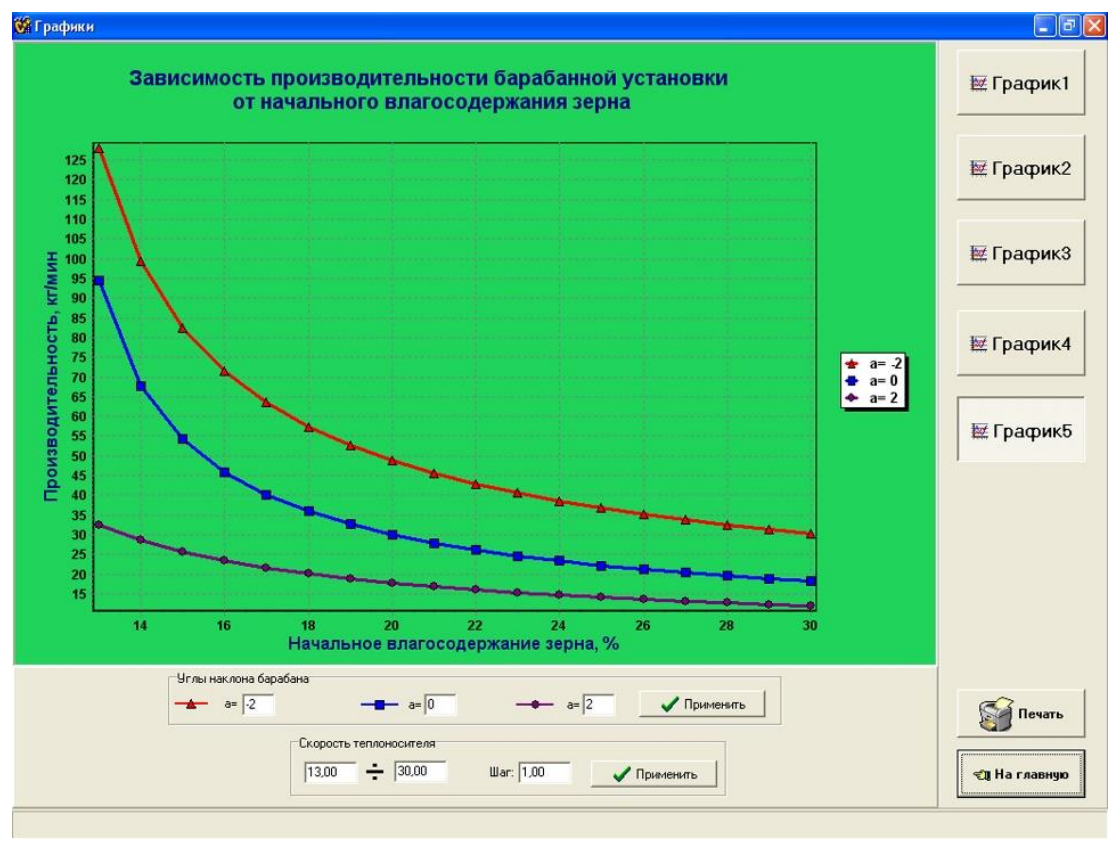

Figure 8 - Drum drying unit productivity of wheat seed humidity graph.

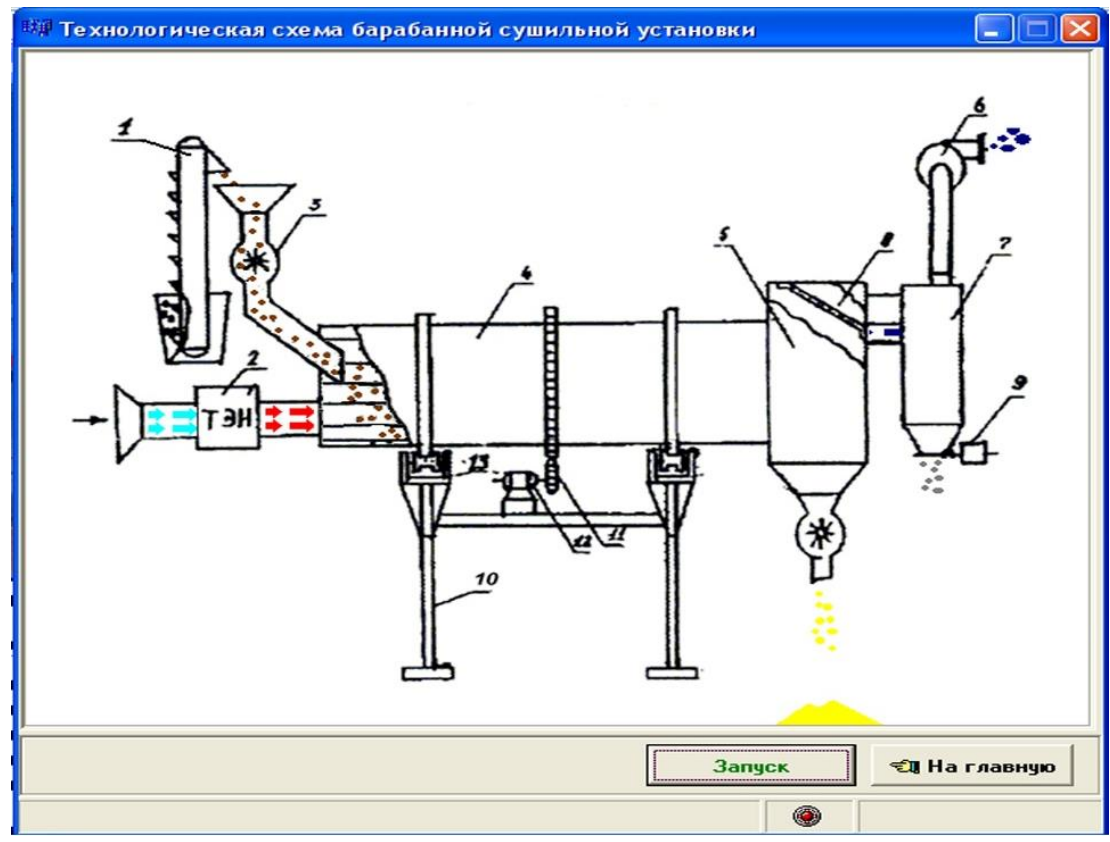

Figure 9 - Drum drying plant process flow diagram.

\section{References:}

1. Kazanov ED, Kretovich VL (1980) Biokhimiya zerna i produktov ego pererabotki. - Moscow: Kolos, 1980.

2. Gerzhoy AP, Samochetov VF (1967) Zernosushenie i zernosushilki. -Moscow: Kolos, 1967. - 253 p.
3. Kazanov ED (1973) Zerno vedenie s osnovami rastenievodstva. -Moscow: Kolos, 1973, -285p.

4. Lynov AV (1990) Sushka v khimicheskoy promyshlennosti. -Moscow: Khimiya, 1990, $429 \mathrm{p}$. 
Impact Factor ISRA (India) $\quad=\mathbf{1 . 3 4 4}$

Impact Factor ISI (Dubai, UAE) $=\mathbf{0 . 8 2 9}$

based on International Citation Report (ICR)

Impact Factor GIF (Australia) $\quad \mathbf{0} \mathbf{0 . 3 5 6}$
Impact Factor JIF $\quad=\mathbf{1 . 5 0 0}$

Impact Factor SIS (USA) $\quad=\mathbf{0 . 9 1 2}$

Impact Factor РИНЦ (Russia) $=\mathbf{0 . 1 7 9}$

Impact Factor ESJI (KZ) $\quad=\mathbf{1 . 0 4 2}$
5. Okun' GS, etc. (1963) Ustanovki dlya sushki zerna za rubezhom. -Moscow: Sel'khozizdat, 1963.

6. Zelenskiy GS, Kal'shnik LI (1999) Rezhimy sushki prodovol'stvennoy pshenitsy na gazovykh retsirkulyatsionnykh zernosushilkakh. -Moscow: Mukomol'naya i elevatornaya promyshlennost' №7, 1999.

7. (1983) Sushil'nye apparaty i ustanovki: Katalog Moscow: TsINTI neftekhimash, 1983. -56p.
8. Grishin MA, Amanazevich VI, Semenov YG (1989) Ustanovki dlya sushki pishchevykh produktov. Spravochnik. -Moscow: Agroproikhdat. 1989. -215p.

9. Altukhov AV (1999) Metodologiya sovershenstvovaniya rascheta barabannykh sushil'nykh agregatov. Aftoreferat, diss.dokt. tekh.nauk, Shymkent, 1999.

10. Arkhangel'skiy AY (2003) Programmirovanie v C++Builder6. Moscow 2003. 